WIDER Working Paper 2018/75

\title{
What does it mean to be poor?
}

Investigating the qualitative-quantitative divide in Mozambique

Sam Jones ${ }^{1}$ and Inge Tvedten ${ }^{2}$

July 2018 
Abstract: This paper reflects on the relationship between economic (quantitative) and anthropological (qualitative) approaches to the analysis of poverty in developing countries. Drawing on detailed evidence from Mozambique, we argue that different research approaches do not merely see the same poverty from different angles; rather, they tend to conceptualize poverty differently. These different views can be traced to alternative philosophical positions along three axes - the ontological character of poverty; its generative mechanisms; and epistemological priorities. The quantitative analysis provides an indispensable numerical snapshot of trends in consumption and its broad correlates over time (e.g. via poverty profiles). In contrast, anthropological work focuses on lived experiences of poverty, which is rooted in a view of poverty as a process of social marginalization. While the policy implications of an economic approach focus on overall economic development and enhancing inputs at the household level, a relational view of poverty suggests the need to address counter-productive relations of power and to carefully target interventions at the poorest. Clarifying the specific philosophical commitments invoked in different forms of poverty research can shed light on the different kinds of research questions they are able to address.

Keywords: poverty, qualitative, anthropology, quantitative, Q-squared, Mozambique

JEL classification: I30, I32, O12, O55

Acknowledgements: We would like to thank Vincent Somville for his helpful comments. All errors and omissions remain our own.

\footnotetext{
${ }^{1}$ University of Copenhagen, Denmark, corresponding author: sam.jones@econ.ku.dk; ${ }^{2}$ Chr. Michelsen Institute, Bergen, Norway.

This study has been prepared within the UNU-WIDER project on 'Inclusive growth in Mozambique — scaling up research and capacity' implemented in collaboration between UNU-WIDER, University of Copenhagen, University Eduardo Mondlane, and the Mozambican Ministry of Economics and Finance. The project is financed through specific programme contributions by the governments of Denmark, Finland, Norway, and Switzerland.
}

Copyright (C) UNU-WIDER 2018

Information and requests: publications@wider.unu.edu

ISSN 1798-7237 ISBN 978-92-9256-517-6 https://doi.org/10.35188/UNU-WIDER/2018/517-6

Typescript prepared by Joseph Laredo.

The United Nations University World Institute for Development Economics Research provides economic analysis and policy advice with the aim of promoting sustainable and equitable development. The Institute began operations in 1985 in Helsinki, Finland, as the first research and training centre of the United Nations University. Today it is a unique blend of think tank, research institute, and UN agency — providing a range of services from policy advice to governments as well as freely available original research.

The Institute is funded through income from an endowment fund with additional contributions to its work programme from Finland, Sweden, and the United Kingdom as well as earmarked contributions for specific projects from a variety of donors.

Katajanokanlaituri 6 B, 00160 Helsinki, Finland

The views expressed in this paper are those of the author(s), and do not necessarily reflect the views of the Institute or the United Nations University, nor the programme/project donors. 
Research on poverty in developing countries has been pursued extensively across the social sciences, and interest in this topic is not dwindling; despite what appear to be significant reductions in monetary poverty over recent decades, many still live in precarious material conditions. A recent estimate places a lower bound on the prevalence of global poverty at nearly 800 million people, of whom more than half are located in sub-Saharan Africa (Ravallion and Chen 2017). At the same time, approaches to poverty analysis from different disciplines within the social sciences are often at odds or speak past one another. As a result, policy-makers (and non-academics) face the complicated task of trying to make sense of highly diverse perspectives on the same issue in a particular context.

The purpose of this study is to take a fresh look at disciplinary divides in the analysis of poverty through the concrete case of Mozambique. Our motivation for doing so is threefold. First, Mozambique is a relevant yet rather complex case. While it has registered one of the strongest and most sustained periods of economic growth of any country since the early $1990 \mathrm{~s}$, monetary poverty in Mozambique remains stubbornly high (INE 2010, 2015; MEF 2016). As outlined in Section 2, close to half of all Mozambicans live in households that cannot afford a minimal basket of goods that meets their basic needs-i.e. rapid economic growth has not mapped into especially fast poverty reduction.

Second, and as in other contexts (e.g. McKay and Lawson 2003), popular and policy narratives about poverty in Mozambique have been dominated by analyses rooted in a quantitative tradition. This is understandable from the point of view of tracking economic conditions at the household level. But, as we will argue, it provides limited insights into the diverse faces of poverty in different areas, how these have evolved over time, and the social processes that (re)produce them. As a consequence, insights that emerge from the prevailing approach remain somewhat superficial, being focused on generic symptoms of material poverty rather than their dynamics and deeper causes.

Our third motivation touches on the personal. Both authors have worked in Mozambique over many years, but mostly sitting in different disciplinary silos-namely, economics and anthropology. We have observed that responses to the dominance of quantitative narratives around poverty in the country have been either to dismiss this kind of analysis (e.g. as technically problematic or lacking in subjective validity) or to commission secondary qualitative studies in order to place a more 'human face' on existing quantitative perspectives. These moves mirror trends in the academic literature. Various contributions in anthropology and sociology are dismissive of standard economic methods used to quantify poverty (Hastrup 1993; Randall and Coast 2015), at times considering them to be actively misleading (see Green 2007).

On the other hand, while attempts to find some form of common methodological ground have proliferated, falling under the rubric of mixed methods or Q-squared studies, many of these ultimately give precedence to quantitative methods (Kanbur 2004; du Toit 2009; Green 2009). That is, household surveys remain a dominant tool but are often tweaked or supplemented by other qualitative modes of data collection, such as life course interviews (e.g. Howe and McKay 2007; Davis and Baulch 2011). Indeed, Starr's (2014) review of qualitative research on poverty considers only studies authored by scholars with a (primary) quantitative or economics background. 
We do not contend that these kinds of mixed approaches should be side-lined (for a review of their contributions see Schaffer 2013). Nonetheless, their typical emphasis on complementary insights risks giving inadequate attention to divergent findings, which can emerge when specific approaches speak on their own terms (Brady and Burton 2016). Using the case of Mozambique, we argue that it is critical to be alert to (more) fundamental differences in philosophical positions, as well as the distinctive practices and forms of knowledge to which these positions give rise. Recognizing philosophical differences points to the kinds of questions that research in different traditions can substantively address. In doing so, we do not seek to prioritize one form of knowledge over another. However, rather than attempting to achieve an integrated analysis of poverty ex ante, such as via modifications to research designs, we suggest that encounters between contrasting views can be productive. And a better understanding of foundational philosophical differences helps prepare the ground for such an encounter.

These arguments are not entirely novel. Various studies highlight the distinctive philosophical positions adopted in anthropological and sociological studies of poverty (e.g. Green 2007; Mosse 2010; De Boeck 2015). Also, Pearce (2015) critiques the simplistic opposition of qualitative and quantitative research approaches and, instead, draws specific attention to differing ontological and epistemological commitments (see also Bevan 2007). However, previous contributions along these lines are mostly made at the level of theory and, where related to poverty, tend not to engage with existing research practices. Our contribution is to lay out the distinctive insights that emerge from two different disciplinary traditions, using a single country case as a vehicle and attempting to remain even-handed in our exposition. In doing so, we are able to identify concrete contrasts in understandings of poverty in Mozambique, as well as some areas of commonality.

The remainder of the paper proceeds as follows: Section 2 begins with a sketch of perspectives on poverty in Mozambique from quantitative (economic) and qualitative (anthropological) positions. The former approach is primarily based on a set of four nationally representative household surveys; and the latter draws on detailed studies undertaken in social formations in different parts of the country over extended periods. Section 3 elaborates on this evidence, showing how these different perspectives invoke contrasting positions along three interconnected domains-namely, their ontological focus; generative mechanisms; and epistemological priorities. These positions are illustrated by specific examples, covering themes such as the conceptual treatment of the household, kin relations, and the role of gender norms. Section 4 reflects on the broader implications of these findings, for both academic research and poverty reduction policy; and Section 5 concludes.

Before we proceed, it may help to clarify what lies outside the scope of this paper. We do not seek to provide a comprehensive or essential definition of 'quantitative' (economic) versus 'qualitative' (anthropological) approaches to poverty. We recognize that the conceptual field of well-being is extremely broad and encompasses a multitude of distinct theoretical traditions, some of which cannot easily be classified as only quantitative or qualitative. Our intention here is not to consider the entire field of welfare theory; and our focus in Mozambique relates to two concrete applications of poverty research. These approaches are widely employed, but they nonetheless represent particular positions within what is a diverse field. Consequently, our depictions of 'quantitative' and 'qualitative' research can be read as having a straw man quality. But this simplification serves a didactic purpose-namely, it helps clarify the specific philosophical commitments that researchers invoke, particularly when it comes to the practical implementation of poverty research within different traditions. These commitments are often overlooked or poorly understood, and it is this gap we seek to illuminate. 


\subsection{Quantitative view}

At least until recently, Mozambique was widely considered a success story in sub-Saharan Africa. After the cessation in the early 1990s of a devastating and prolonged conflict, the country sustained aggregate rates of economic growth of around 8 per cent per year up until the mid-2010s. This growth has been accompanied by solid progress on many social indicators, such as infant mortality and school enrolment. Nonetheless, in part due to the low base associated with the legacy of conflict, the country continues to rank comparatively poorly on many standard development metrics, such as average GDP per capita and the Human Development Index (UNDP 2017; World Bank 2017). Despite recent setbacks related to large-scale corruption in connection with undisclosed government debt (Orre and Rønning 2017), prospects for sustained economic growth appear robust, largely due to considerable activity associated with the extraction of coal and offshore gas deposits.

Throughout the past 25 years, poverty reduction has been high on the political agenda. This is evidenced by the adoption of various national poverty reduction strategies, which have served as a common framework for substantial support to the government budget by foreign donors. As elsewhere, government policies and academic debates around poverty have been dominated by economic approaches to poverty measurement-i.e. the main focus has been on progress against an absolute national poverty line, quantified using a cost of basic needs (CBN) approach. As set out in Ravallion (1998), the CBN approach is grounded in a money-metric notion of utility, which postulates that a given level of utility (welfare) can be expressed in monetary terms. Of itself, this says nothing about any particular level of welfare below which an individual is deemed to be poor. The distinctive feature of the CBN approach is that it anchors welfare to the level of per capita expenditure required to meet minimum food and non-food needs. This is intended to constitute a fixed, consistent welfare threshold referenced to 'normative activity levels appropriate to [economic] participation in society' (Ravallion 1998: 30). This welfare-consistent poverty line is measured as the sum of the costs of: (i) a bundle of food that provides sufficient nutrition to maintain active bodily functioning and normal levels of work (e.g. around 2,100 kcal per day for adult males); and (ii) a minimal allowance for non-food consumption, such as shelter and clothes.

Within a money-metric utility framework, the value and composition of the consumption bundle required to achieve a given level of welfare is expected to vary over time and space, particularly due to differences in prices. This is generally addressed by using actually observed information, taken from detailed surveys, about the prices of available goods alongside household expenditure shares on different items. Together, these are used to cost a 'typical' bundle of goods aligned to the chosen basic needs welfare threshold in different locations. ${ }^{1}$ Therefore, while the nominal value of the poverty line is expected to vary over time (and space), the underlying concept of poverty — namely, deficient purchasing power in relation to a minimal set of goods-is held fixed.

In Mozambique, nationally representative surveys of households have been undertaken in 1996/97, 2002/03, 2008/09, and 2014/15 by the government's statistics agency (Instituto Nacional de Éstatistica, INE). These have included detailed budget modules and constitute the primary data

\footnotetext{
${ }^{1}$ Whether or not households actually consume this bundle is beside the point. We also recognize that subjective approaches to identifying reference levels of welfare are gaining ground in economics. While these developments are welcome, most approaches do not substantively depart from the money-metric view of poverty. Thus, they are not discussed further here.
} 
from which a CBN approach and ancillary quantitative analyses have been elaborated (e.g. DNEAP 2010; Arndt et al. 2012; Arndt and Tarp 2016; MEF 2016). Descriptive statistics from these surveys are presented in Table 1 and Figure 1. These indicate that following reductions in the aggregate consumption-based (official) poverty rate from 69 to 53 per cent between 1996/97 and 2002/03, the share of the population living in poverty has fallen more slowly, reaching 46 per cent in 2014/15. Over the full period, this equates to relatively slow consumption growth for most of the population. As indicated in the top row of the table, the median household has registered real consumption growth of just 2.1 per cent per year since 1996. The same evidence suggests that the depth and severity of poverty have almost stagnated over the past decade; and that urban areas have benefited much more from economic growth over the most recent period. This is evidenced by a large jump in real income inequality, shown by the Gini coefficient.

Table 1: Metrics of poverty and inequality in Mozambique 1996/97-2014/15

\begin{tabular}{lrrrrr}
\hline & $1996 / 97$ & $2002 / 03$ & $2008 / 09$ & $2014 / 15$ & Growth \\
\hline No. consumption baskets & 0.7 & 1.0 & 1.0 & 1.1 & $2.1 \%$ \\
Poverty headcount & 68.8 & 52.7 & 51.5 & 46.3 & $-2.2 \%$ \\
Poverty gap & 28.7 & 19.3 & 19.0 & 16.7 & $-3.0 \%$ \\
Squared poverty gap & 15.3 & 9.5 & 9.7 & 8.3 & $-3.4 \%$ \\
Gini (x100) & 40.5 & 41.5 & 41.7 & 46.8 & $0.8 \%$ \\
\hline
\end{tabular}

Notes: 'No. consumption baskets' reports the number of baskets equal in value to the Cost of Basic Needs poverty line that the median household can purchase; the poverty gap and its square are expressed as a proportion of the poverty line; growth is annualized over the full period.

Source: Own calculations from household survey microdata.

Figure 1: Metrics of poverty in Mozambique 1996/97-2014/15, by rural and urban locations (\%)
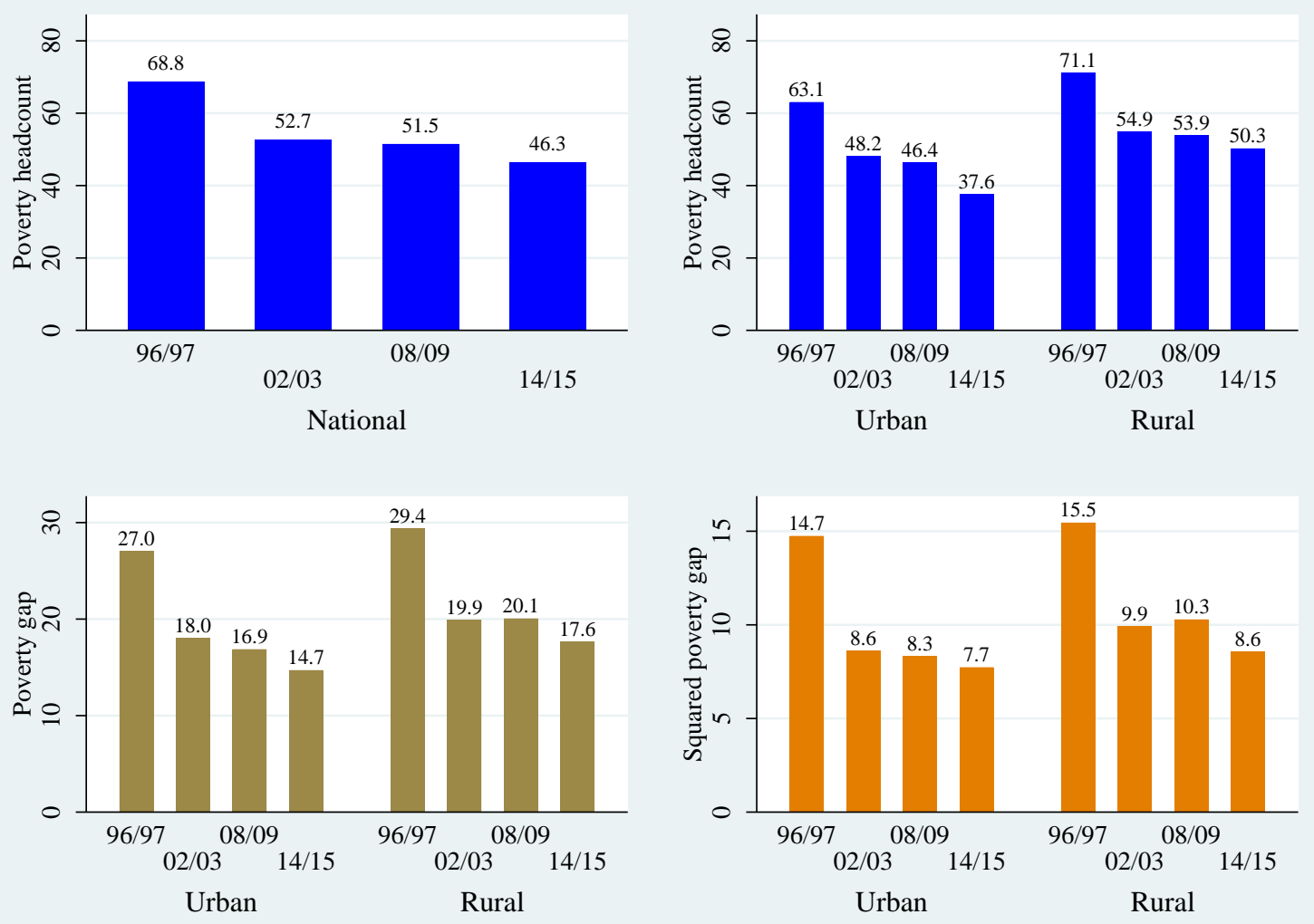

Source: Own calculations from household survey microdata. 
In addition to these core outcomes, there are many ways in which household survey data can be analysed. Here we restrict ourselves to a review of some of the specific combinations of characteristics that tend to be associated with being poor or non-poor. In keeping with a kind of poverty profile, these can be isolated from a regression of the log. welfare ratio (multiplied by 100), defined as the logarithm of the number of consumption baskets equal in value to the poverty line available to each household member, on a set of household characteristics (for similar exercises see Datt et al. 2000; Datt and Jolliffe 2005). If a household is poor, then the log. number of such consumption baskets is less than zero. Note that the unit of observation is the household, not the individual; and we use declared consumption rather than income to evaluate poverty. This reflects the challenge, found in many lower income countries, that a large share of economic activity is undertaken outside formal employment (e.g. in small-scale agriculture). In turn, consumption levels (values) are best measured on a joint household basis.

The explanatory variables used in the regression model are fairly standard. They encompass the characteristics of the head of the household and other members (number of members of different types, education levels of working members, etc.). We also include dummy variables for the main forms of income-generating activities undertaken by the household. Following Jones and Tarp (2013, 2016) we classify households into four mutually exclusive categories, reflecting their predominant form of economic activity. These are: (a) households exclusively engaged in smallholder agriculture (the default category, not shown); (b) households that engage in some agriculture but also have non-farm activities (denoted 'ag. and non-farm household'); (c) non-farm household enterprises, which are exclusively engaged in non-farm activities but generally in the informal sector; and (d) households exclusively dependent on wage labour. Last, we include dummy variables for the province of residence and, where relevant, we add a location dummy (rural/urban) and a time trend. The latter captures the average rate of consumption growth not explained by changes in observed characteristics over time.

Results from this exercise are reported in Table 2. Column (1) represents a pooled regression, covering all households surveyed in Mozambique over the four rounds, including location (province) fixed effects and a time trend. ${ }^{2}$ The remaining columns represent sub-sample regressions: columns (2) and (3) continue to pool the survey rounds but allow separate estimates for rural and urban locations; and columns (4) to (7) report estimates for each survey separately (across all locations).

What do we learn from this analysis? First, larger households with more dependants (young children) display lower per capita consumption and, thus, higher rates of poverty. In part, this finding may reflect the technical challenge of how to represent economies of scale within each household, which is addressed here by making no adjustments for adult equivalence (as per the country's official poverty analysis). Second, we find differential returns to male and female labour, as well as between 'youth' (aged 15-25) and 'adult' (aged 25-65) workers. The default category, not shown, refers to young men in exclusively agricultural households in the Niassa province. So, the positive and significant coefficients on the three categories of working-age members (male and female adults plus young women) indicates that young men contribute least to household consumption. Also, with the exception of the latest survey round (column 7), female adults contribute most to per capita consumption on average. Overall, the results show that the demographic structure of households matters very much for well-being.

\footnotetext{
${ }^{2}$ The most recent survey round interviewed (mostly) the same full set of households in three different survey quarters. The full set of quarterly observations is included, but household weights are rescaled (downward) such that the pooled sum of household weights matches the (target) population size.
} 
Table 2: Regression results explaining numbers of baskets of real consumption per household per capita

\begin{tabular}{|c|c|c|c|c|c|c|c|}
\hline \multirow{2}{*}{$\begin{array}{l}\text { Location } \rightarrow \\
\text { Survey year } \rightarrow\end{array}$} & \multirow{2}{*}{$\begin{array}{c}\text { National } \\
\text { All }\end{array}$} & \multicolumn{2}{|c|}{ By location (pooled) } & \multicolumn{4}{|c|}{ By year } \\
\hline & & Urban & Rural & $1996 / 97$ & $2002 / 03$ & $2008 / 09$ & $2014 / 15$ \\
\hline Column $\rightarrow$ & (1) & $(2)$ & $(3)$ & $(4)$ & $(5)$ & (6) & $(7)$ \\
\hline \multirow[t]{2}{*}{ Age of household head } & $-0.3^{\star \star \star}$ & $-0.2^{*}$ & $-0.2^{\star \star}$ & -0.2 & -0.1 & $-0.4^{\star \star}$ & 0.0 \\
\hline & $(0.1)$ & $(0.1)$ & $(0.1)$ & $(0.1)$ & $(0.1)$ & $(0.1)$ & $(0.1)$ \\
\hline \multirow[t]{2}{*}{ Is household head female? } & 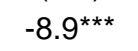 & $-9.3^{\star \star \star}$ & $-9.7^{\star \star \star}$ & $-11.2^{\star \star \star}$ & $-10.5^{\star \star}$ & $-6.8^{\star \star}$ & $-12.0^{\star \star \star}$ \\
\hline & $(1.2)$ & $(1.7)$ & $(1.5)$ & $(2.4)$ & $(3.3)$ & $(2.4)$ & $(1.3)$ \\
\hline \multirow[t]{2}{*}{ Household size } & $-2.6^{\star \star \star}$ & 0.1 & $-8.1^{\star \star \star}$ & $-18.1^{\star \star \star}$ & $-7.5^{\star \star \star}$ & -0.3 & $-7.4^{\star \star \star}$ \\
\hline & $(0.7)$ & $(0.7)$ & $(1.1)$ & $(2.1)$ & $(2.1)$ & $(0.9)$ & $(0.8)$ \\
\hline \multirow{2}{*}{ Adult males (\% household) } & $62.7^{\star \star \star}$ & $73.1^{\star \star \star}$ & $60.7^{\star \star \star}$ & 16.4 & $47.5^{\star \star \star}$ & $60.5^{\star \star \star}$ & $64.8^{\star \star \star}$ \\
\hline & $(3.7)$ & $(5.8)$ & $(5.1)$ & $(8.5)$ & $(9.0)$ & $(7.9)$ & $(4.2)$ \\
\hline \multirow[t]{2}{*}{ Adult female members (\%) } & $74.6^{\star \star \star}$ & $90.9^{\star \star \star}$ & $70.8^{\star \star \star}$ & $30.6^{\star \star \star}$ & $64.7^{\star \star \star}$ & $68.9^{\star \star \star}$ & $67.3^{\star \star \star}$ \\
\hline & $(4.3)$ & $(6.1)$ & $(6.3)$ & $(8.9)$ & $(9.3)$ & $(9.8)$ & $(4.4)$ \\
\hline \multirow[t]{2}{*}{ Young female members (\%) } & $54.6^{\star \star \star}$ & $51.8^{\star \star \star}$ & $56.6^{\star \star \star}$ & $49.9^{\star \star \star}$ & $39.5^{\star \star \star}$ & $46.1^{\star \star \star}$ & $38.1^{\star \star \star}$ \\
\hline & $(4.8)$ & $(8.0)$ & $(6.6)$ & $(9.7)$ & $(11.3)$ & $(10.3)$ & $(5.4)$ \\
\hline \multirow[t]{2}{*}{ Household members <7 years (\%) } & $-7.4^{\star \star \star}$ & $-11.0 * * *$ & $-3.4^{\star \star \star}$ & $-5.7^{\star \star \star}$ & $-7.9 * * *$ & $-7.2^{\star * \star}$ & $-8.0^{\star \star \star}$ \\
\hline & $(0.8)$ & $(1.1)$ & $(1.0)$ & $(1.4)$ & $(1.7)$ & $(1.6)$ & $(0.7)$ \\
\hline \multirow[t]{2}{*}{ Household members 7-14 (\%) } & $-6.9 * \star \star$ & $-9.6^{\star \star \star}$ & $-2.1^{*}$ & $-5.5^{\star \star \star}$ & $-7.1^{\star \star \star}$ & $-6.8^{\star \star \star}$ & $-5.1^{\star \star \star}$ \\
\hline & $(0.7)$ & $(0.8)$ & $(1.0)$ & $(1.2)$ & $(1.4)$ & $(1.3)$ & $(0.7)$ \\
\hline \multirow[t]{2}{*}{ Years of education (workers) } & $2.1^{\star \star \star}$ & $4.5^{\star \star \star}$ & $3.1^{\star \star \star}$ & $7.1^{\star \star \star}$ & -0.5 & 1.0 & 0.4 \\
\hline & $(0.4)$ & $(0.7)$ & $(0.6)$ & $(1.0)$ & $(1.2)$ & $(1.0)$ & $(0.4)$ \\
\hline \multirow[t]{2}{*}{ Years of education (workers) sqrd. } & $0.6^{\star \star \star}$ & $0.5^{\star \star \star}$ & $0.2^{\star \star}$ & $0.3^{*}$ & $0.9^{\star \star \star}$ & $0.7^{\star \star \star}$ & $0.6^{\star \star \star}$ \\
\hline & $(0.0)$ & $(0.0)$ & $(0.1)$ & $(0.1)$ & $(0.1)$ & $(0.1)$ & $(0.0)$ \\
\hline \multirow[t]{2}{*}{ Ag. and non-farm household } & $19.4^{\star \star \star}$ & $18.7^{\star \star \star}$ & $20.6^{\star \star \star}$ & $18.0^{\star \star \star}$ & $19.9^{\star \star \star}$ & $13.3^{\star \star \star}$ & $22.0 * \star \star$ \\
\hline & $(1.5)$ & $(2.3)$ & $(2.0)$ & $(3.2)$ & $(3.5)$ & $(3.5)$ & $(1.5)$ \\
\hline \multirow[t]{2}{*}{ Non-farm enterprise household } & $37.8^{\star \star \star}$ & $35.1^{\star \star \star}$ & $46.5^{\star \star \star}$ & $31.1^{\star \star \star}$ & $46.5^{\star \star \star}$ & $39.4^{\star \star \star}$ & $36.3^{\star \star \star}$ \\
\hline & $(1.9)$ & $(2.3)$ & $(4.4)$ & $(5.2)$ & $(4.7)$ & (4.6) & $(1.8)$ \\
\hline \multirow[t]{2}{*}{ Household is wage earning } & $30.4^{\star \star \star}$ & $27.0^{\star \star \star}$ & $38.4^{\star \star \star}$ & $12.8^{*}$ & $35.3^{\star \star \star}$ & $21.0^{\star \star \star}$ & $35.5^{\star \star \star}$ \\
\hline & $(2.1)$ & $(2.4)$ & $(5.6)$ & $(5.7)$ & $(5.1)$ & $(4.3)$ & $(2.1)$ \\
\hline
\end{tabular}




\begin{tabular}{|c|c|c|c|c|c|c|c|}
\hline \multirow{2}{*}{$\begin{array}{l}\text { Location } \rightarrow \\
\text { Survey year } \rightarrow\end{array}$} & \multirow{2}{*}{$\begin{array}{l}\text { National } \\
\text { All }\end{array}$} & \multicolumn{2}{|c|}{ By location (pooled) } & \multicolumn{4}{|c|}{ By year } \\
\hline & & Urban & Rural & $1996 / 97$ & $2002 / 03$ & 2008/09 & $2014 / 15$ \\
\hline \multirow[t]{2}{*}{ Province: Cabo Delgado } & 3.1 & $15.7^{\star \star \star}$ & -0.1 & $14.9^{\star \star}$ & $-27.8^{\star \star \star}$ & -5.7 & $20.9 * \star \star$ \\
\hline & $(2.0)$ & $(4.1)$ & $(2.2)$ & $(4.9)$ & $(4.1)$ & $(4.2)$ & $(2.4)$ \\
\hline \multirow[t]{2}{*}{ Province: Nampula } & $-6.8^{\star \star \star}$ & 5.2 & $-9.3^{\star \star \star}$ & -4.5 & $-15.1^{\star \star \star}$ & $-22.4^{\star \star \star}$ & $5.2^{\star \star}$ \\
\hline & $(1.8)$ & (3.1) & $(2.1)$ & (4.3) & $(4.2)$ & $(4.1)$ & $(1.9)$ \\
\hline \multirow[t]{2}{*}{ Province: Zambézia } & $-8.0^{\star \star \star}$ & -4.8 & $-9.3^{\star \star \star}$ & 5.4 & -5.6 & $-38.2^{\star \star \star}$ & $4.2^{\star}$ \\
\hline & $(1.8)$ & (3.2) & $(2.1)$ & $(4.0)$ & $(4.4)$ & $(4.0)$ & $(2.0)$ \\
\hline \multirow[t]{2}{*}{ Province: Tete } & -1.6 & $-13.1^{\star \star \star}$ & -0.9 & $-18.7^{\star \star \star}$ & $-36.9^{\star \star \star}$ & $-15.7^{\star \star}$ & $35.5^{\star \star \star}$ \\
\hline & (2.0) & $(3.4)$ & (2.3) & $(4.3)$ & $(4.7)$ & $(4.8)$ & $(2.2)$ \\
\hline \multirow[t]{2}{*}{ Province: Manica } & 2.4 & $12.6^{\star \star \star}$ & 0.9 & $26.4^{\star \star \star}$ & -9.3 & $-34.0^{\star \star \star}$ & $26.8^{\star \star \star}$ \\
\hline & (2.1) & (3.1) & (2.5) & $(4.7)$ & (5.5) & $(4.2)$ & $(2.1)$ \\
\hline \multirow[t]{2}{*}{ Province: Sofala } & $-5.3^{\star}$ & $14.6^{\star \star \star}$ & $-12.7^{\star \star \star}$ & $-34.3^{\star \star \star}$ & $11.4^{\star}$ & $-38.2^{\star \star \star}$ & $27.3^{\star \star \star}$ \\
\hline & $(2.5)$ & $(3.0)$ & $(3.4)$ & $(4.5)$ & $(5.0)$ & $(6.5)$ & $(2.3)$ \\
\hline \multirow{2}{*}{ Province: Inhambane } & $-20.5^{\star \star \star}$ & $10.6^{\star \star}$ & $-27.6^{\star \star \star}$ & $-15.4^{\star \star \star}$ & $-68.6^{\star \star \star}$ & $-19.9^{\star \star \star}$ & $14.6^{\star \star \star}$ \\
\hline & $(2.3)$ & $(3.5)$ & $(2.8)$ & $(4.4)$ & $(5.1)$ & $(5.4)$ & $(2.4)$ \\
\hline \multirow{2}{*}{ Province: Gaza } & -2.9 & $16.0^{\star \star \star}$ & $-6.3^{\star}$ & $20.2^{\star \star \star}$ & $-9.8^{\star}$ & $-40.7^{\star \star \star}$ & $13.3^{\star \star \star}$ \\
\hline & (2.3) & $(3.7)$ & $(2.8)$ & $(4.9)$ & $(4.7)$ & $(5.6)$ & $(2.6)$ \\
\hline \multirow[t]{2}{*}{ Province: Maputo } & $-6.9 * \star$ & $11.3^{\star \star \star}$ & $-22.8^{\star \star \star}$ & 8.4 & $-48.8^{\star \star \star}$ & $-48.3^{\star \star \star}$ & $45.4^{* \star *}$ \\
\hline & $(2.3)$ & $(3.0)$ & $(3.4)$ & (5.9) & $(4.6)$ & $(5.2)$ & $(2.2)$ \\
\hline \multirow[t]{2}{*}{ Province: Maputo City } & $9.9^{\star \star \star}$ & $18.2^{\star \star \star}$ & - & 6.1 & $-26.7^{\star \star \star}$ & $-18.0^{\star \star \star}$ & $57.3^{\star \star \star}$ \\
\hline & $(2.4)$ & $(2.9)$ & & (7.1) & $(5.2)$ & $(5.3)$ & $(2.4)$ \\
\hline \multirow[t]{2}{*}{ Rural location (dummy) } & $19.2^{\star \star *}$ & - & - & $13.0 * \star \star$ & $18.9 * \star \star$ & $15.1^{\star \star \star}$ & $28.1^{\star \star \star}$ \\
\hline & $(1.2)$ & & & (3.3) & $(2.7)$ & $(2.5)$ & $(1.3)$ \\
\hline \multirow[t]{2}{*}{ Time trend (in years) } & $1.4^{\star \star \star}$ & $0.8^{\star \star \star}$ & $1.5^{\star \star \star}$ & - & - & - & - \\
\hline & $(0.1)$ & $(0.1)$ & $(0.1)$ & & & & \\
\hline Observations & 54,981 & 26,237 & 28,744 & 7,645 & 8,192 & 10,013 & 29,131 \\
\hline R-squared (adjusted) & 0.30 & 0.41 & 0.22 & 0.34 & 0.32 & 0.26 & 0.41 \\
\hline
\end{tabular}

Notes: The outcome is each household's log. number of consumption baskets that are equal to the poverty line; column (1) pools all surveys; columns (2) and (3) separate by location (rural/urban); columns (4)-(7) refer to individual surveys; the baseline category, not shown, is young males (aged 15-24) in Niassa province (urban) exclusively engaged in smallholder agriculture; adults are defined as aged 25-64; only selected coefficients are shown; robust standard errors are given in parentheses.

Source: Own estimates from household survey microdata. 
Third, we note that the returns to education (measured here only for household members who are workers) are generally low and convex-i.e. education makes a substantial difference to consumption only at comparatively high levels. The survey-specific results also suggest that the shape of returns to education has been shifting over time. In the latest round, for instance, the expected consumption increment associated with completing the first cycle of primary school (5 years of education) relative to no schooling equals just 18 per cent, which is around half of the return obtained in 1996/97. Fourth, the classification of households by primary activity is systematically related to their poverty status. Households that are not exclusively engaged in agriculture typically have per capita consumption at least 13 per cent higher than those dependent on smallholder farming; and this is consistent across time and space. While access to wage work is generally a consistent indicator of a relatively higher level of household consumption, non-farm household enterprises in fact appear to do moderately better than wage-dependent households in all locations and periods. This confirms the potential for urban informal activities to generate reasonable economic returns, on average (see also Jones and Tarp 2015).

These results substantiate the official narrative that poverty in Mozambique is broadly associated with: low levels of education; larger numbers of dependent family members; and low returns to economic activities in (rural) agriculture versus manufacturing and services (DNEAP 2010; MEF 2016). At the same time, some more thought-provoking findings emerge. First, while femaleheaded households tend be to poorer than male-headed households, the conditional difference in consumption is moderate (at 9 per cent) and somewhat lower in urban than rural areas. Second, as indicated by the coefficients on the provincial location effects, there is a huge variation in average consumption levels both between provinces and within provinces over time. For example, holding all other covariates fixed, average consumption was more than 45 per cent lower in Maputo province than in Niassa (the reference province) in both 2002/03 and 2008/09, but was 45 per cent higher in the latest survey round. This variation has sparked some controversy and, at least in part, may reflect quality issues in the consumption data (see the discussion in MEF 2016). Even so, material variation-especially in rural areas-remains broadly consistent with slow growth in agricultural productivity and a high frequency of both positive and negative shocks, inducing large price variability (Arndt et al. 2012). Put simply, many households remain highly vulnerable to variations in external economic conditions and, in the absence of liquid savings or substantial food buffer stocks, their consumption levels vary accordingly.

\subsection{Qualitative view}

Parallel to the quantitative national household surveys, a series of six qualitative studies on poverty were carried out. These aimed to view development and poverty 'from below', taking the perspective of the poor, and were carried out in selected locations covering different social formations in different parts of Mozambique: the northern district of Murrupula in Nampula province, representing a rural social formation (Tvedten et al. 2006, 2010); the southern city of Maputo, representing an urban social formation (Paulo et al. 2007, 2011); and the central district of Buzi in Sofala province, finding itself at the urban-rural interface (Rosário et al. 2008; Picardo et al. 2012). Each of the initial three studies (2006-2008) was followed up after three years (20092011) in order to ascertain changes in poverty and well-being over time-revisiting the same local administrations, communities, and households as in the first round of studies. A similar series of qualitative studies on poverty was carried out in urban (Cuamba) and rural (Majune and Lago) areas in the province of Niassa over a period of five years from 2011 to 2015 (see Tvedten et al. 2016).

These studies, which we draw on here, explicitly took an anthropological approach to the study of poverty, which meant dispensing with a focus on a particular consumption threshold, below which households are deemed to be poor. This is not because analysts in this tradition necessarily reject 
the possibility that deficient consumption is a relevant aspect of poverty. Rather, the focus on a particular level of material welfare misdirects attention from what are considered more crucial domains of structural constraints and human agency/social relations-often with reference to various versions or aspects of a 'practice theory' framework (Bourdieu 1990; Ortner 2006; Mosse 2010; Moore and Sanders 2014). ${ }^{3}$ Under this view, individuals are embedded in political, economic, and cultural structures that have a powerful effect upon actions and the shape of events. While there is room for social change through human agency, the approach highlights economic positions and social asymmetry as the most relevant dimensions of both structure and agency. Moreover, the approach emphasizes the primacy of social relations. Society does not consist of bounded units of individuals or households, but the sum of connections and relationships in which people find themselves.

In addition, an anthropological view brings 'culture' - in the sense of ideas and modes of thought - into the equation as a key basis for human action (Ortner 2005; Small et al. 2010). Culture resides in a set of public forms related to issues such as 'inequality' and 'otherness', rendered meaningful when people interpret and act upon them (Hannerz 1992; Moore and Sanders 2014). In this way, people act rationally in relation to their poverty and well-being-not as a universal homo economicus, but with reference to a specific socio-cultural context that needs to be understood (Helgesson 2005; Gudeman 2008). In turn, the primary focus of the qualitative studies was on how structural constraints become encoded in social relations that reproduce different types of 'oppression', viewed as an absence of genuine opportunities for exerting agency in a specific locale. Thus, the 'lived experiences' of poverty are assumed to matter in a more profound and complex way than in the economic tradition (Green 2007).

The methodological kernel of the qualitative studies was longitudinal ethnographic fieldwork. Field observation and participation was complemented by a set of participatory methodologies applied in focus groups (e.g. community problem matrix and wealth ranking), which aimed to capture the community's own perceptions of different levels and categories of poverty and well-being. These were further supplemented by a total of 25 expanded case studies ('immersion') at household level, selected from the different locally defined categories of poverty in each study site (Mikkelsen 2005; Hesse-Biber and Johnson 2015). Finally, a set of semi-structured interviews with local powerholders and decision-makers was also used to gain an understanding of authority structures as well as the perceptions of elites regarding poverty and development in each area.

The focus groups were asked to define what poverty means to them and how types/levels of poverty are differentiated according to their own conceptualizations and vernacular. These 'emic' definitions of poverty are summarized in Table 3 and reveal a twofold notion of what it means to be poor. On the one hand, poverty is undoubtedly about material deficiency and particularly a lack of what are considered basic assets, such as housing. But on the other hand-and no less importantly-poverty is perceived to reflect the strength and nature of social relationships, which are seen as vital to coping with poverty/vulnerability and achieving social mobility. That is, being poor is intimately connected to one's perceived 'place' in a wider society and one's scope for (upward) movement. Indeed, as the table shows, the respondents were consistently alert to whether people are captured in structural poverty, without possibilities for change.

\footnotetext{
${ }^{3}$ While anthropology is a multifaceted discipline with a number of distinct sub-disciplines, the widely read volume Anthropology in Theory. Issues in Epistemology (Moore and Sanders 2014) highlights various forms of 'pracsis theory' as one of the main 'red threads' in the history of the discipline.
} 
Table 3: Local categorizations of poverty and well-being

\begin{tabular}{|c|c|c|c|}
\hline Category // Location & Murrupula & Maputo & Buzi \\
\hline \multicolumn{4}{|l|}{ The poor } \\
\hline The destitute poor & opitanha & xiculungo & umbwa \\
\hline The chronically poor & ohawa & xantumbuluku & mulombo \\
\hline The transient poor & ohikalano & xangamo & kombo \\
\hline \multicolumn{4}{|l|}{ The better-off } \\
\hline The permanently rich & opwalatha & xantumbuluku & muthende \\
\hline The newly rich & ovela & xigogo & mucupuki \\
\hline Language & Macua & Shangana & Ndau \\
\hline
\end{tabular}

Notes: Cells give the local word for each category of household/individual; Language is the dominant local language in each location.

Source: Own compilation.

Focus group discussions, case studies, and observations showed that the essence of being a 'destitute' is not extreme material need per se, but social marginalization and exclusion, which makes people vulnerable, powerless, and isolated. For the non-rich, a distinction is made between people who are 'caught' in material poverty and only manage on a day-to-day basis (the 'chronically poor') versus those who have resources and social relations that make social mobility possible via hard work (the 'transient poor'). For the better-off, a distinction is made between people who are born 'permanently' rich and people who have become rich by their own hard work or 'luck'. Also, everybody considered 'rich' needs to balance their external signs of success carefully (in land, housing, commodities, etc.) with concomitant social responsibilities for sharing.

In all three locations, we found substantial consistency in people's broad categorizations, perceptions, and experiences of what poverty means and the forms it takes. However, some variations were found, particularly between rural (Murrupula and Buzi) and urban (Maputo) areas. These appear largely to reflect differences in the relative importance (role) of money. In Maputo, a commodification of social relations relates the level of poverty and well-being more explicitly to income than in both Murrupula and Buzi, where social relations with the extended family, neighbours, and the community are generally considered more important (see Table 3). We return to this theme below.

The focus groups were also asked about the distribution of people in each category in their community, taking ten households in their immediate neighbourhood as a point of departure. The poorest category of 'destitutes' was usually seen to represent one or two out of ten, the 'chronically' and 'transient poor' six to eight and the 'rich' categories one or two. Also in this case there were striking similarities between Murrupula/Buzi and Maputo, despite the fact that quantitative data reveal considerable differences in consumption/levels of inequality between rural and urban areas in particular. This shows that poverty and well-being are understood within society in predominantly relative terms. In Murrupula and Buzi, having a tin roof and a bicycle were seen as signs of wealth. In Maputo, wealth was associated with large brick houses and cars in a shantytown context where people were constantly reminded of the affluence in the formal/rich parts of the city (see also Bertelsen et al. 2014).

As for the other 'poor' categories, even small negative shocks-e.g. in agricultural production, informal sector income, school fees, medical expenses, or support from extended family-may set them on a course of downward social mobility. In Murrupula, we encountered a single mother who had lost large parts of her harvest to drought two years in a row. She had struggled hard to put all her three children through school, but with no crops to sell she could no longer pay the bribe (gasosa) necessary for her children to move up classes. Her biggest sorrow was that 'they will end up like me'. 
For 'poor' and 'rich' households experiencing improved circumstances, such as through production, income, and social support, the challenge is to use these for their own investment and further upward mobility, rather than for enhanced immediate consumption by the household and/or extended family. The social pressure to share seems strongest in rural Murrupula and Buzi, but the implications of failure are largest in Maputo, where social safety networks appear more limited. An older entrepreneur in Niassa, who had been seen by people in his home village not to have maintained social relations and given sufficient support to the community, experienced the ultimate sign of social marginalization when hardly anybody attended his funeral.

\section{Contested positions}

The previous section offered two different views on poverty in Mozambique. The quantitative view highlighted (changes) in command over basic goods at the household level as the object of enquiry and identified a variety of factors associated with greater effective consumption power. The qualitative view emphasized the place of individuals (and families) within a web of social relations, seeing the degree of poverty as multifaceted and crucially dependent on the possibility of drawing on those relations for support and/or social mobility.

These two views might easily be seen as complementary. Both accounts generally acknowledge a connection between material privation and poverty. In turn, one might envisage methodological innovations in quantitative data collection practices to capture some of the additional nuances revealed by the qualitative research. For instance, the qualitative distinction between transitory and permanent forms of poverty might be captured by longitudinal data on the same households, allowing one to distinguish between those who remain consumption poor and those who move in and out of poverty. This would correspond to certain definitions of chronic poverty, where duration of time without adequate consumption/income is a defining feature (McKay and Lawson 2003). The social aspect of poverty indicated by the qualitative research might also be addressed via survey-based measures of 'social capital', which could then be added to the set of factors used to explain variation in consumption (e.g. Maluccio et al. 2000) and/or poverty durations (e.g. Zhang et al. 2017).

As noted in the Introduction, methodological moves to embrace qualitative insights are not uncommon and have deepened our understanding of poverty in various contexts (see Camfield et al. 2009; Camfield and Roelen 2013). However, even when they expand the definition of who can be classified as poor, perhaps by combining data on material outcomes with subjective perceptions regarding capabilities and agency, many studies retain an ultimate interest in counting and profiling in reference to a given yardstick of well-being (e.g. Pradhan and Ravallion 2000; McGregor et al. 2007). The downside of these kinds of methodological extensions is that they tend to overlook the contrasting philosophical positions which underpin different disciplinary approaches and which do not admit any simple elision. To develop and clarify this argument, this section considers three theoretical domains (axes) in which contrasting philosophical positions point to fundamentally distinct conceptualizations of what it means to be poor. These domains are summarized in Table 4 and we discuss each in turn, drawing further on our evidence from Mozambique.

Table 4: Summary of contrasting philosophical positions, by general domain

\begin{tabular}{lll}
\hline Domain & 'Quantitative' & 'Qualitative' \\
\hline Ontological character & Realist/external & Constructed/internal \\
Generative mechanisms & Economic factors & Social relations \\
Epistemological priority & Representativity (etic) & Thick description (emic) \\
\hline = Philosophy of science & Naturalism & Anti-naturalism \\
\hline
\end{tabular}

Source: Authors' construction. 


\subsection{Ontological character}

The first domain refers to the ontological character of poverty, by which we mean what kind of a 'thing' it is. Here, a key distinction is between realist and anti-realist positions (Mäki 2008). The former takes poverty as a mind-independent, externally verifiable (objective) fact. This is echoed in the earlier quantitative definition of poverty as the material condition of deficient consumption. So, leaving aside technical challenges around the actual measurement of consumption, poverty can be identified without reference to other social objects or perceptions thereof. That is, we need only look at external consumption patterns to classify individuals as poor. The contrasting position posits that being poor cannot be separated from the social-i.e. it is not meaningful to think of poverty without reference to social relations and how people are perceived in relation to one another.

The second (qualitative) position yields a view of poverty as a fluid and variegated lived experience constituted through social relations of inclusion and exclusion (Harriss 2009; Woolcock 2009). Consequently, the essential character of being poor is not just low consumption or inadequate assets (although these material conditions are often found as well). Rather, it involves being perceived as meriting a low relative social status and can only be exposed and interpreted with reference to specific local meanings and social dynamics. Consistent with the emphasis of Mosse (2010), this amounts to an inescapably relational view of poverty (see also Green 2009). By this, we cannot seek to understand poverty as a mechanical outcome given by the absence of a set of inputs or attributes (e.g., on social capital, see Cleaver 2005). Rather, the experience of poverty can be seen as an unfolding of processes of social marginalization (in the context of class analysis, see Marsh et al. 2007; Carrier and Kalb 2015).

How do these different ontological positions play out in more concrete terms? Two examples suffice. First, the processual and relational view of poverty adopted in (some) qualitative research does not admit a neat distinction between inputs (causes) and outputs (effects) (see also McGregor et al. 2007). This is evident in how the household is conceptualized and treated in poverty research. In the quantitative surveys discussed in Section 2.1, the household is defined in static terms as those people 'eating from the same pot and living under the same roof' (INE 2008: 26). This definition does not really emerge from any special theoretical considerations. ${ }^{4}$ It is largely a convenient choice that facilitates the estimation (measurement) of consumption across individuals at a low level of aggregation. If it were practically feasible to differentiate consumption patterns at the individual level (i.e. within households), then that would remain consistent with a definition of poverty as low consumption and provide an even more fine-grained view. The point is that the demographic characteristics (and other attributes) of each household are treated as exogenous (given) from the point of view of measuring consumption and identifying who is poor.

Many qualitative (anthropological) studies also use the household as a basic social and analytical unit. However, these approaches tend to do away with a perception of the household as easily bounded or static. Instead, they stress the permeability of households in time and space, as they adapt to structural constraints, opportunities, and shocks (Moore 1994; O'Laughlin 2007; Randall and Coast 2015). Anthropological studies also move away from an understanding of the household solely as a social unit mobilizing around common economic interests and, instead, emphasize the household as a locus of competing social interests and obligations, particularly around gender and age. As a consequence of the former, intra-household relations are seen as significantly affected

\footnotetext{
${ }^{4}$ Joint production of goods by the household can motivate analysis at this level. However, this does not preclude that levels of consumption (and poverty status) can vary across individuals within the household.
} 
by political, economic, and social processes outside the household; and as a consequence of the latter, those processes are understood to affect individual household members in diverse ways.

In line with this view, the qualitative studies of poverty (outlined in Section 2.2) found that households went through continuous changes in terms of de jure and de facto headship, as well as size and composition during the study period. Also, emic definitions of the household give emphasis to people who 'eat from the same pot' (in an abstract and broad social sense) but without necessarily living under the same roof or even physically eating together on a regular basis. Following individual households from the different categories of poverty and well-being over time revealed continuous processes of fusion and fission, particularly involving non-core household members (i.e. extended family or non-family relations). In Buzi, for example, a common strategy for social mobility/poverty alleviation among rich/better-off households is to 'split' the household into a rural and an urban unit - the former producing food, the latter earning money, and children continuously changing location depending on their age and education, and labour requirements. Households in the very poorest/destitute category in Murrupula usually do not have this option because of the initial investments it requires. There, many older women in particular see their household size increase with grandchildren their mothers and fathers cannot take care of.

In Maputo, households are under strong pressure to maintain relations with rural areas of origin by taking in distant as well as non-family members, often on a semi-permanent basis. As a result, many urban households were larger than the rural households we encountered. Also, in all three settings, either de jure or de facto polygamy is common. The poorest families have no choice but to marry away daughters at a young age to have fewer mouths to feed and acquire bride wealth (lobolo). For their part, well-off male household heads marry (or relate to) more than one woman because it gives prestige and is a way to maintain vital social relations and hoard opportunities (see Tilly 1998; Mosse 2010). In Niassa, we met an entrepreneur who had married a total of five wives during a period of 20 years - significantly expanding his extended family network. He used this to diversify his economic interests (commerce, transportation, construction, and fishing), primarily employing extended family members with the explicit argument that 'they can be trusted' (but also, according to one of these relatives, so as to be able to pay lower wages).

A second example is the importance accorded to the subjectivities or 'inner life' of the poor (Ortner 2005). Evidently, this aspect is not generally considered within quantitative approaches to poverty measurement, as it is not seen as relevant to the problem of identifying who is poor. ${ }^{5}$ However, the qualitative studies revealed that many of the destitute (chronically poor) exhibited a sense of hopelessness and despair, having effectively given up on making more of their lives by investing for the future. We met destitute people in both rural Murrupula/Buzi and Maputo who resorted to short-term or ad hoc actions that seemed to perpetuate or even worsen their situation and who also seemed unable to respond to opportunities emerging through structural changes. In Maputo, with more tangible gaps between the poorest and the better-off, as well as more restricted and commodified social networks, the sense of hopelessness and defeat among the most destitute was particularly evident. Some men remained in peripheral city areas (bairros) all day, instead of going to central areas where work may be found; women stopped insisting that their children go to school because it is 'no use'; and some young people engaged in sexual and other relations that they knew might be detrimental to their health or future, but yielded short-run advantages (see Groes-Green 2013).

\footnotetext{
${ }^{5}$ We note that psychologists and behavioural economists are increasingly interested in the 'mindset' associated with poverty, such as the negative affective states it may produce (Haushofer and Fehr 2014).
} 
These findings suggest that processes of social marginalization can become self-reinforcing-i.e. individuals come to know what to expect or what is expected from them in their social interactions; they then adapt their life plans to this restrictive ecology, in some cases seeing the particular set of material circumstances and social relations as 'normal' to them. In turn, this can aggravate their own destitution (Wacquant 1992; see also Tvedten 2011). For example, a destitute and socially isolated household in Niassa, consisting of four generations of women, chose to invest an unusual but meagre contribution from a relative in a fence around their reed hut, which had been trespassed by the villagers. The reason given by them was: 'in order not to be ashamed any more'.

\subsection{Generative mechanisms}

Contrasting positions regarding the ontological character of poverty (what it means to be poor) map closely to different views about how poverty is (re)produced. In part, these generative mechanisms merit separate treatment since the quantitative approach remains largely silent here. The econometric exercise of Table 2 expresses a set of conditional correlations. The regression estimates point to factors systematically associated with differences in household consumption, but they do not reveal why these factors vary across households. Take the example of education. The regressions suggest that greater exposure to formal education is associated with higher levels of consumption and, thus, lower poverty. Even if this reflects a causal relationship, it does not explain how it is that some households accumulate substantial education and others do not (historically and today). Put differently, the quantitative analysis points to the likely effects of various immediate determinants/correlates of consumption, but it says nothing about what lies behind the actually existing distribution of these determinants (the causes of the determinants).

That said, the quantitative analysis does place an emphasis on conventional economic determinants of poverty. While this is not strictly necessary since non-economic factors might be admitted (e.g. metrics of social capital), the procedure is nevertheless aligned toward quantifiable factors that can be conceived of as inputs into a (set of) household production or expenditure function(s) (e.g. Michael 1975). Consequently, this mode of analysis tends to conceptualize the causes of poverty in the same functional terms-e.g. as a lack of inputs or their low level of sophistication/ productivity. This is not intended to downplay the econometric analysis. But it does clarify the intended scope and direction of this kind of approach, which is descriptive and functional/ mechanical.

The emphasis of qualitative studies on how poverty unfolds inherently demands closer attention to the mechanisms involved. Furthermore, the relational nature of poverty suggests that the constellation and practices of power, understood as forces that affect both the perceived and actual room for manoeuvre of households and individuals, are likely to be crucial (Mosse 2010). In the Mozambican case, we find that these relations of power and authority are strong, especially in rural Murrupula and Buzi. In particular, it is highly unusual for anybody to directly challenge those in positions of authority-i.e. for the poor to challenge the rich, for the young to challenge elders, for the lay to challenge religious/traditional authorities, or for women to challenge men. Together this helps maintain a status quo in areas/sectors that arguably most need to change if poverty is to be reduced.

The effects of traditional authority are less pronounced in urban Maputo, but are largely substituted by party political and economic forms of oppression and marginalization. In Niassa, the national District Development Fund had become the main source of money for investment in economic activities - with the goal of reducing rural poverty (Orre and Rønning 2017). Ostensibly, priority was to be given to agriculture rather than businesses, women rather than men, and associations rather than individuals. However, we saw that the funds had been systematically coopted by influentes including traditional authorities, (male) entrepreneurs, and the local Frelimo 
party elite through an intricate system of informal regulations and bribes. Thus, the local elite had effectively hoarded the opportunities afforded by these funds (Tilly 1998; also Tvedten and Picardo 2018). In Maputo, the poorest bairros remain systematically excluded from municipal services such as solid waste collection. While this has devastating implications for people's well-being and dignity, local authorities (bairro administrators, heads of quarters) remain passive. In large part this seems to be because these authorities are loyal party members and, to protect their reputations/ positions, are quick to close down any signs of protest or local action (see also Tvedten and Candiracci 2018).

Kinship systems are also an important mechanism through which social power and economic resources are organized and channelled. But the relative importance of these systems of kinship differs between the rural and urban settings. In matrilineal Murrupula, the mother's extended family matters most, her children 'belong' to her family, and the mother's oldest brother remains the most important person for a young person growing up. According to one interlocutor, the really poor are those who do not have a maternal uncle (tio) to support them. In Buzi, the patrilineal kinship system has been largely dismantled, except for the tradition of bride wealth (lobolo), which ties many women to marriages they would like to get out of and prohibits them from accumulating their own money to become independent of their husbands. In Maputo, urban life has led to a 'commodification' of social relationships where kinship has lost much of its content and an increasing number of exchanges are with neighbours and friends, and through work-related social relationships (including participation in rotating savings clubs, xitique). The poorest usually do not have relations with colleagues or others with economic means, and primarily relate to people in the same situation as themselves, which tends to perpetuate or even worsen their situation.

Gender norms further act to cement specific relationships and ways of being. For most of our interlocutors, the main alternative to agriculture is the informal economy, often engaging in petty trade or basic services. But here we find clear gender-based differences in the types of activities undertaken by men (transport, trade in commodities) and women (services, trade in foodstuffs). In Murrupula, socio-cultural constraints inhibit women from taking an active part in informal economic activities-evidenced by the dominance of men in informal markets. However, in Maputo and Buzi, women are generally more effective than men in terms of establishing viable/effective social networks through e.g. associations and churches-often explained by interlocutors as a question of trust (confiança). Even so, we observed that informal activities pursued by men tend to pay better than activities pursued by women.

For the better-off with sufficient resources to make some fixed initial investment, setting up a small (home) enterprise represents an alternative to agricultural and informal trade. While such investments are often achieved by drawing on social (kin) relations, entrepreneurs in Murrupula and Buzi in particular tend to diversify into a range of smaller enterprises and reinvest revenues in their social network, by marrying more wives and employing family members and relatives. Thus, these activities do not meet the usual economic criteria of innovation and deployment of physical capital assets to only generate income and employment (Desai 2009). Diversifying economically reduces risks in unstable economic contexts. By diversifying and investing socially, the not only does entrepreneur make sure to fulfil perceived responsibilities in a context where not doing so may have severe repercussions, but he also aims to (further) enhance his social status and power, ensuring ongoing influence through the local community. In Maputo, however, establishing an enterprise is seen as strictly more of an individual economic endeavour, with larger potential gains but also larger risks of failure. Furthermore, in a large city the social influence of even a small successful entrepreneur is easily eclipsed by official authority and those with links to senior political figures. 
The series of qualitative studies also exposed the importance of what may be called spiritual control mechanisms, such as witchcraft (Moore and Sanders 2001; Geschiere 2013). Witchcraft has a strong impact on economic position and social relationships, particularly in rural areas in Mozambique, where many seen as 'non-productive', such as elders, are further marginalized through witchcraft accusations. It is also an effective measure applied against households and individuals who are seen to improve themselves at the expense of others, such as successful farmers who increase their land holdings and use (often minimally paid) local labour. Accusations of witchcraft effectively cut off opportunities for further expansion. In Murrupula, a family from the neighbouring district of Gurue had established itself and secured land for a larger commercial farm. However, they eventually had to give up due to witchcraft accusations following from the combination of being foreigners (estrangeiros) in the community and producing more than others. These accusations made it impossible to recruit the necessary labour.

These examples point to a range of social mechanisms that (re)produce experiences of poverty in Mozambique, defined here as social marginalization or low relative status. Nonetheless, two nuances are in order. First, social relations are not simply 'given' but are constantly renegotiated and (in some cases) actively contested. For example, in matrilineal and Muslim Murrupula, men continue to be vested with the responsibility for provisioning as well as authority and decisionmaking power within the household - to the extent that men are always given food before their wives and children. However, male dominance is no longer a given. Particularly in Maputo, but also in small-town Buzi, household headship and authority is gradually becoming an issue of employment, income and house/dwelling ownership rather than gender. We followed several households with a living male spouse that came to be seen as female-headed when the latter became the main income provider. There is also a high proportion of female-headed households in the communities in question. While such households in Murrupula/Buzi still tend to be stigmatized and marginalized, many of the female heads of households in Maputo have made a deliberate choice to live alone with their children, thereby achieving greater financial and social autonomy.

Second, while the qualitative evidence points to social mechanisms that both sustain a status quo of unequal social relations and distribute opportunities for social mobility in specific ways, these mechanisms may have their roots in deeper historical, economic, and political tendencies. Scholars in various traditions have frequently located these tendencies in transformations associated with (late) capitalism (e.g. Comaroff and Comaroff 2001; Harriss-White 2006). It is beyond the scope of this paper to elaborate on these tendencies for our case. Besides, in somewhat similar fashion to the quantitative analysis, to do so would require us to read beyond the immediate empirical evidence and draw on broader theoretical models of development processes. However, as indicated, the qualitative evidence does suggest that economic transformations — often induced by external events such as new infrastructure or an opening-up of markets-can open the door to a reconfiguration of social and economic relations. This can help break traditional constraints; but it also brings new forms of dependencies and asymmetries. For instance, many lower income households in urban Maputo are now finding that employment does not necessarily depend on leveraging existing family or kin ties. Instead, access to wage employment frequently rests on the ability to pay intermediaries through a widespread system of bribes to brokers or employees, usually in the form of the first two months' wages. More broadly, the increasing commodification of social relationships that is evident in urban settings of Mozambique arguably leads to more pronounced concentrations of power and a narrowing of potential pathways out of poverty.

\subsection{Epistemological priority}

Ontology and epistemology are closely intertwined. Here we are interested in the kind of knowledge that different approaches tend to prioritize. We have noted that the quantitative 
approach is focused on measuring the incidence of poverty, defined in a strict material sense. Theoretically, the approach aims to construct and apply a consistent money-metric welfare standard across space and time. As we have demonstrated, further auxiliary analysis of consumption data can provide insights into how poverty varies with various household-level characteristics. Overall, the approach reflects an underlying etic epistemology-i.e. the objects of analytical interest are abstract and have greater meaning for the observers than for the observed. This is consistent with a form of knowledge that renders the social and economic landscape not only legible but also something that can be acted upon-e.g. via the design and implementation of bureaucratic interventions, such as targeted welfare schemes.

The epistemology associated with more qualitative positions is emic, prioritizing lived experiences (of the poor) rather than abstract and pre-given notions of poverty. The emic/etic contrast may be mundane, but it is important because the emic impetus is not to flatten and distil lived experiences into concrete bytes of actionable bureaucratic knowledge (on the disjuncture between bureaucratic and local knowledge, see Sainath 1996). Rather, it remains intentionally open to the complex, uncertain, and inherently asymmetric conditions under which social and economic processes (may) unfold. So, rather than seeking to achieve a representative and sufficiently large sample, the emic drive is toward a rich understanding of individual experiences and their particular context. It follows that our understanding of poverty as the experience/process of social marginalization is difficult - if not impossible — to adequately quantify in a meaningful way across time and space. Also, analyses focusing on the household as a fixed and bounded unit cannot meaningfully relate to social relationships, either internal or external to the unit itself, and cannot persuasively incorporate issues of structural oppression and/or emic perceptions.

We finish this section with two cases from the qualitative studies: one of a socially isolated household effectively trapped in poverty and the other of a household in a position to use social relations for upward social mobility.

'Maria' is a woman of around 40 years of age, living in Murrupula. When we met her, she was very sick and said she suffered from pneumonia (often a euphemism for HIV/AIDS). Her dwelling was in poor shape, and she had only two small fields around her house. Although she had been poor before even before it, her misfortune had started five years earlier, when her husband left her to go to Nampula. In accordance with tradition, her husband's family had come to claim what they considered to be his property. 'Maria' originally came from Zambézia, and therefore had no one to turn to for help and was not able to go back to her own family. With her lived one of her daughters, who had three children, and a granddaughter, who seemed to be 13 or 14 and was pregnant with her second child. They all seemed apathetic, and claimed that they had only the two small fields to rely on. None of them received support from the fathers of their children. Most of the interview was undertaken with Maria's son, who was 15. He had gone to school for two years, and seemed very bright. He made a little money from working in other people's fields, which, he argued, made their own fields suffer. The son simply could not see any way out of their problems. He claimed that they had no family or friends, and that even neighbours did not help them. 'People will not help somebody as poor as us,' he said, 'because they know we cannot give them anything in return'.

'Fernando', born in 1964, lives in Buzi and has two wives and eight children, of whom four still live with him. He had risen to fortune through a combination of luck, hard work, and investment in social relations. In the late 1990s, Fernando had moved to the town from a rural part of the district, where he had been 'a normal farmer', and started to work as a 'helper' on one of the many canoes that transport goods and people via the Buzi River to the city of Beira. Once, the canoe capsized and goods costing 'a lot of money' fell overboard and were considered wasted. However, he went back, managed to collect some of them, and claims that the goods started him off as a 
successful comerciante. In building up his business, he had used a large set of contacts and relationships: he initially used his own family to work in the small commercial stalls (bancas) he set up ('they are the only ones who can really be trusted'), and then expanded his business to rural areas by involving traditional leaders (régulos and saguta) as business partners. Later he expanded his business considerably, first with a loan from the District Development Fund to buy a small truck for transport to and from Beira—selling fish and buying commodities—and then by opening an agricultural field to produce cash crops. At the time of our second fieldwork, three years later, Fernando was one of the wealthiest people in Buzi and had married a third wife.

\section{$4 \quad$ Implications}

The previous section discussed key domains in which social scientists take contrasting positions in the analysis of poverty. We now reflect on the academic and policy implications of these arguments. With respect to the former, a key issue is that the contrasting positions (ontological and epistemological) are indicative of fundamental disciplinary tensions. It is not that qualitative and quantitative researchers tend to see the same thing (poverty) from different angles. Rather, we suggest, they often see things differently; and the forms of knowledge they generate are distinct. Consequently, while certain forms of research that seek a more integrated understanding of poverty (e.g. by tweaking survey tools or expanding the notion of poverty to embrace deprivation in multiple dimensions) can be valuable, innovations to quantitative methods do not suddenly resolve these fundamental tensions. In most cases, such tweaked (quantitative plus) approaches retain a realist ontology and etic epistemology. It should be noted that this simply serves as a description, not a normative critique. A more general point is that alternative philosophical positions serve particular ends and provide answers to different kinds of questions.

The above goes some way to explaining some of the challenges that poverty researchers face when moving from a theory of poverty to practical implementation and measurement. Take, for instance, Sen's capability approach. As Robeyns (2006) notes, this approach may be considered as 'postdisciplinary' in the sense that it is of sufficient generality to anchor practical implementations of both a quantitative and a qualitative nature. However, while the framework may indeed provide a common theory and language for research, embracing views of poverty as both resource deficiency and limited agency (oppression), it is evident that it remains 'radically underspecified and every application requires additional specifications [...] [so] there are always a number of different ways in which a particular question can be answered using the capability approach' (Robeyns 2006: 371). In the argument of this paper, the 'specifications' that must be added necessarily invoke specific philosophical commitments, and it is these positions that can yield fundamentally different types of assessments, despite being attached to the same general theoretical framework.

An implication for the measurement of poverty (in both academic and policy research) is that cherishing different methodological approaches is vital precisely because of their diversity. An exclusive use of quantitative approaches is likely to provide only a description of (changes to) material conditions and the distribution of consumption across different aggregates (regions, types of households, etc.). This is useful; but it is difficult to see how this evidence alone can shed much light on the unequal and socially layered processes of development taking place. On the other hand, a unique reliance on richer anthropological studies may miss the broader sweep of changes in material conditions over time and provide little concrete guidance on where policy-makers should look to support the poorest. Indeed, while quantitative and qualitative approaches may somewhat overlap in terms of identifying who is poor, their understandings of what poverty is and the mechanisms that produce it are dissimilar. Consequently, a forced marriage of qualitative and 
quantitative approaches risks losing their inherent diversity of perspectives, which comes from the different ways of seeing poverty.

The final policy implication for Mozambique concerns the slow pace of poverty reduction observed across much of the country, especially since the early/mid-2000s. Neither the quantitative nor the qualitative studies provide a definitive explanation of why this has been the case. However, a focus on poverty as deficient consumption at the household level naturally suggests that the deficiency can be addressed by providing households with improved access to income-generating opportunities and various forms of capital (education, health, etc.). Indeed, quantitative approaches prioritize the roles of exogenous changes in economic conditions and the ways in which access to new and larger markets (e.g. in urban agglomerations) provide an impetus for wider processes of transformation.

A focus on structural oppression and the social relations of marginalization goes beyond the household as a bounded unit and focuses on the position of the poor in local power relations. From this viewpoint, poverty alleviation interventions should deal with the underlying bases of oppression and marginalization. These relate to the activities of: the state (exclusion of the poor from democratic institutions, petty corruption, unequal access to education, health services, physical infrastructure, etc.); the private sector (discriminatory terms of employment, low minimum wages, exploitative prices for agricultural products, illegalization of informal economic activities, etc.); local communities (marginalization of the poor by traditional authorities and community-based organizations, unequal distribution of agricultural land, evictions from shantytowns, etc.); and broader socio-cultural practices or norms (unequal gender relations, witchcraft accusations, discrimination against elders, etc.). So, in addition to standard economic policy priorities, development policies are needed that will confront counter-productive relations of power and authority by supporting greater opportunities for local political voices to challenge oppressive social practices as well as carefully targeting support to the very poorest. Moreover, greater attention must be given to how standard economic policy interventions are reconfigured by existing elites for their own benefit, as shown in the example of the District Development Fund in Niassa.

\section{Conclusions}

The aim of this paper was to reflect on the ways in which quantitative and qualitative analyses of poverty relate to one another. One motivation was that (recent) mixed-methods scholarship on poverty has tended to give precedence to quantitative approaches, with qualitative insights largely used as complementary devices, such as to add depth of interpretation or tweak an initial survey design. Our argument has been that, although this kind of combination has its place, a search for common ground may conceal the distinctive insights associated with different social science traditions. Using the case of Mozambique, we argued that these distinctive insights have their roots in contrasting philosophical positions with respect to the ontological character of poverty, the relevant generative mechanisms, and their associated epistemologies. Contrasting positions in these domains are not easily reconciled. Rather, they serve as a base from which to address substantively different research questions and generate distinct forms of knowledge around poverty.

Economic analysis of poverty in Mozambique has had a high profile, being used by both foreign aid donors and the government as a key metric of governmental performance. From the perspective of providing a broad, representative measure of trends in well-being (consumption) this kind of analysis is valuable. However, economic analysis has limitations, particularly in terms 
of understanding what poverty entails and how it varies in nature/form across space and time. Qualitative studies of poverty experiences, based on research in a range of communities across the country, reveal some similarities but also key differences in comparison with economic notions of poverty. Particularly in rural areas, the notion that poverty only means having insufficient command over goods was found to be inadequate. Emic notions of chronic poverty or destitution refer to experiences of exclusion from the local community and an absence of voice and/or agency. Our qualitative studies also revealed consistent differences in structural constraints and opportunities, particularly between the rural, matrilineal and Muslim Murrupula in the north and Buzi in the central region, as well as between rural and urban social formations (Maputo having the lowest poverty rate).

In sum, disciplinary tensions between practical economic and anthropological research on poverty can be a source of productive insights. Allowing work in different traditions to stand on its own feet and speak on its own terms reveals points of both convergence and divergence. If nothing else, exploring insights from different traditions can also be a source of critical questions and highlight implicit assumptions in other perspectives. Given the complexity of poverty, embracing a genuine plurality of approaches and insights, including those of the poor, seems appropriate. 


\section{References}

Arndt, C., and F. Tarp (eds) (2016). Measuring Poverty and Wellbeing in Developing Countries. Oxford: Oxford University Press.

Arndt, C., M.A. Hussain, E.S. Jones, V. Nhate, F. Tarp, and J. Thurlow (2012). 'Explaining the Evolution of Poverty: The Case of Mozambique'. American Journal of Agricultural Economics, 94(4): 854-72.

Bertelsen, B.E., S. Roque, and I. Tvedten (2014). 'Engaging, Transcending and Subverting Dichotomies: Discursive Dynamics of Maputo’s Urban Space.' In: Urban Studies, 5(13): 2752 69.

Bevan, P. (2007). 'Researching Wellbeing across the Disciplines: Some Key Intellectual Problems and Ways Forward'. In: I. Gough and J.A. McGregor (eds), Well-Being in Developing Countries. Cambridge: Cambridge University Press, pp. 283-315.

Bourdieu, P. (1990). The Logic of Practice. Stanford: Stanford University Press.

Brady, D., and L.M. Burton (eds) (2016). The Oxford Handbook of the Social Science of Poverty. Oxford: Oxford University Press.

Camfield, L., and K. Roelen (2013). 'Household Trajectories in Rural Ethiopia: What Can a Mixed Method Approach Tell Us About the Impact of Poverty on Children?' Social Indicators Research, 113(2): 729-49.

Camfield, L., G. Crivello, and M. Woodhead (2009). 'Wellbeing Research in Developing Countries: Reviewing the Role of Qualitative Methods'. Social Indicators Research, 90(1): 5-31.

Carrier, J.G., and D. Kalb (eds) (2015). Anthropologies of Class: Power, Practice and Inequality. Cambridge: Cambridge University Press.

Cleaver, F. (2005). 'The Inequality of Social Capital and the Reproduction of Chronic Poverty'. World Development, 33: 893-906.

Comaroff, J., and J.L. Comaroff (eds) (2001). Millennial Capitalism and the Culture of Neoliberalism. Durham: Duke University Press.

Datt, G., and D. Jolliffe (2005). 'Poverty in Egypt: Modeling and Policy Simulations'. Economic Development and Cultural Change, 53(2): 327-46.

Datt, G., K. Simler, S. Mukherjee, and G. Dava (2000). 'Determinants of Poverty in Mozambique: 1996-97'. IFPRI Working Paper 78. Washington, DC: International Food Policy Research Institute (IFPRI).

Davis, P., and B. Baulch (2011). 'Parallel Realities: Exploring Poverty Dynamics Using Mixed Methods in Rural Bangladesh'. The Journal of Development Studies, 47(1): 118-42.

De Boeck, F. (2015). "Poverty" and the Politics of Syncopation. Urban Examples from Kinshasa'. Current Anthropology, 56(Supplement 11): 146-58.

Desai, S. (2009). 'Measuring Entrepreneurship in Developing Countries'. WIDER Working Paper 2009/10. Helsinki: UNU-WIDER.

DNEAP (2010). 'Pobreza e bem-estar em Moçambique: Terceira avaliação nacional'. Technical report, Ministry of Planning and Development, Government of Mozambique. Available at: www.mef.gov.mz/index.php/sobre-o-ministerio/atribuicoes-e-competencias/17-sobre-oministerio/estudo-e-politicas/32-pobreza-e-bem-estar-em-mocambique-terceira-avalicaonacional (accessed 3 July 2018). 
du Toit, A. (2009). 'Beyond "Q-Squared”' Approaches to Understanding Chronic Poverty in South Africa'. In: T. Addison, D. Hulme, and R. Kanbur (eds), Poverty Dynamics. Interdisciplinary Perspectives. Oxford: Oxford University Press.

Geschiere, P. (2013). Witchcraft, Intimacy, and Trust: Africa in Comparison. Chicago: University of Chicago Press.

Green, M. (2007). 'Representing Poverty and Attacking Representations: Perspectives on Poverty from Social Anthropology'. The Journal of Development Studies, 42(7): 1108-29.

Green, M. (2009). 'The Social Distribution of Sanctioned Harm: Thinking through Chronic Poverty, Durable Poverty and Destitution'. In: T. Addison, D. Hulme, and R. Kanbur (eds), Poverty Dynamics. Interdisciplinary Perspectives. Oxford: Oxford University Press.

Groes-Green, C. (2013). 'To Put Men in a Bottle: Eroticism, Kinship, Female Power, and Transactional Sex in Maputo, Mozambique'. American Ethnologist, 40(1): 102-17.

Gudeman, S. (2008). Economy's Tension. The Dialectics of Community and Market. New York and Oxford: Berghahn Books.

Hannerz, U. (1992). Cultural Complexity. Studies in the Social Organisation of Meaning. New York: Columbia University Press.

Harriss, J. (2009). 'Bringing Politics Back into Poverty Analysis. Why Understanding of Social Relations Matters More for Policy on Chronic Poverty than Measurement'. In: T. Addison, D. Hulme, and R. Kanbur (eds), Poverty Dynamics. Interdisciplinary Perspectives. Oxford: Oxford University Press.

Harriss-White, B. (2006). 'Poverty and Capitalism'. Economic and Political Weekly, 41(13): 1241-46.

Hastrup, K. (1993). 'Hunger and the Hardness of Facts'. Man, 28: 727-39.

Haushofer, J., and E. Fehr (2014). 'On the Psychology of Poverty'. Science, 344(6186): 862-67.

Helgesson, G. (2005). 'Rationality in Economics: An Interdisciplinary Debate'. In: S. Löfving (ed.), Peopled Economies. Conversations with Stephen Gudeman. Uppsala: Interface.

Hesse-Biber, S., and R. Burke Johnson (2015). The Oxford Handbook of Multimethod and Mixed Methods Research Inquiry. Oxford: Oxford University Press.

Howe, G., and A. McKay (2007). 'Combining Quantitative and Qualitative Methods in Assessing Chronic Poverty: The Case of Rwanda'. World Development, 35: 197-211.

INE (2008). Inquerito sobre Orcamento Familiar IOF 2008/09. Manual do Inqueridor. Maputo: Instituto Nacional de Estatística.

INE (2010). Inquérito sobre Orçamento Familiar 2008/09. Quadros Básicos. Maputo: Instituto Nacional de Estatística.

INE (2015). Relatório Final do Inquérito ao Orcamento Familiar-IOF 2014/15. Maputo: Instituto Nacional de Estatística.

Jones, S., and F. Tarp (2013). 'Jobs and Welfare in Mozambique'. WIDER Working Paper 2013/045. Helsinki: UNU-WIDER.

Jones, S., and F. Tarp (2015). 'Priorities for Boosting Employment in Sub-Saharan Africa: Evidence for Mozambique’. African Development Review, 27(S1): 56-70.

Jones, S., and F. Tarp (2016). 'Mozambique: Jobs and Welfare in an Agrarian Economy'. In: G. Betcherman and M. Rama (eds), Jobs For Development: Challenges and Solutions in Different Country Settings. Oxford: Oxford University Press. 
Kanbur, R. (2004). 'Q-Squared? A Commentary on Qualitative and Quantitative Poverty Appraisal'. Paper presented at the conference 'Q-Squared in Practice. Experiences of Combining Qualitative and Quantitative Approaches in Poverty Analysis', Toronto 15-16 May.

Mäki, U. (2008) 'Scientific Realism and Ontology'. In: The New Palgrave Dictionary of Economics. London: Palgrave Macmillan.

Maluccio, J., L. Haddad, and J. May (2000). 'Social Capital and Household Welfare in South Africa, 1993-98'. The Journal of Development Studies, 36(6): 54-81.

Marsh, D., T. O'Toole, and S. Jones (2007). Young People and Politics in the UK, Apatby or Alienation? Basingstoke: Palgrave Macmillan.

McGregor, J.A., A. McKay, and J. Velazco (2007). 'Needs and Resources in the Investigation of Well-being in Developing Countries: Illustrative Evidence from Bangladesh and Peru'. Journal of Economic Methodology, 14(1), 107-31.

McKay, A., and D. Lawson (2003). 'Assessing the Extent and Nature of Chronic Poverty in Low Income Countries: Issues and Evidence'. World Development, 31: 425-39.

MEF (2016). 'Pobreza e bem-estar em Moçambique: Quarta avaliação nacional (IOF 2014/15)'. Ministério de Economia e Finanças, Direcção de Estudos Económicos e Financeiros. Available https://www.wider.unu.edu/sites/default/files/Final_QUARTA\%20AVALIA\%C3\%87A O\%20NACIONAL\%20DA\%20POBREZA_2016-10-26_2.pdf (accessed 3 July 2018).

Michael, R.T. (1975). 'Education and Consumption'. In: T. Juster (ed.), Education, Income, and Human Behavior. Cambridge, MA: National Bureau of Economic Research.

Mikkelsen, B. (2005). Methods for Development Work and Research. a New Guide for Practitioners. London: Sage Publications.

Moore, H. (1994). A Passion for Difference. Essays in Anthropology and Gender. Cambridge: Polity Press.

Moore, H., and T. Sanders (eds) (2001). Magical Interpretations, Material Realities: Modernity, Witchcraft and the Occult in Post-Colonial Africa. London: Routledge.

Moore, H., and T. Sanders (2014) Anthropology in Theory. Issues in Epistemology. Oxford: Wiley Blackwell.

Mosse, D. (2010). 'A Relational Approach to Durable Poverty, Inequality and Power'. The Journal of Development Studies, 46: 1156-78.

O’Laughlin, B. (2007). 'A Bigger Piece of a Very Small Pie: Intrahousehold Resource Allocation and Poverty Reduction in Africa'. Development and Change, 38(1): 21-44.

Orre, A., and H. Rønning (2017). The Political Economy of Mozambique. Oslo: Norwegian Institute of International Affairs.

Ortner, S.B. (2005). 'Subjectivity and Cultural Critique'. Anthropological Theory, 5(1): 31-52.

Ortner, S.B. (2006). Anthropology and Social Theory. Culture, Power, and the Acting Subject. Durham and London: Duke University Press.

Paulo, M., C. Rosário, and I. Tvedten (2007). “Xiculungo”. Social Relations of Urban Poverty in Maputo, Mozambique’. CMI Report 2007:13. Bergen: Chr. Michelsen Institute.

Paulo, M., C. Rosário, and I. Tvedten (2011). “Xiculungo” Revisited: Assessing the Implications of PARPA II in Maputo 2007-2010’. CMI Report 2011:1. Bergen: Chr. Michelsen Institute. 
Pearce, L. (2015). 'Thinking Outside the Q Boxes: Further Motivating a Mixed Research Perspective'. In: S.N. Hesse-Biber and R. Burke Johnson (eds), The Oxford Handbook of Multimethod and Mixed Methods Research Inquiry. Oxford: Oxford University Press.

Picardo, R., I. Tvedten, and M. Paulo (2012). “Mucupuki” Revisited. Assessing the Implications of PARP/A in Central Mozambique 2008-2011'. CMI Report 2012:6. Bergen: Chr. Michelsen Institute.

Pradhan, M., and M. Ravallion (2000). 'Measuring Poverty Using Qualitative Perceptions of Consumption Adequacy'. Review of Economics and Statistics, 82(3), 462-71.

Randall, S., and E. Coast (2015). 'Poverty in African Households: The Limits of Survey and Census Representations'. The Journal of Development Studies, 52(2): 162-77.

Ravallion, M. (1998). 'Poverty Lines in Theory and Practice'. Living Standards Measurement Study Working Paper 133. World Bank.

Ravallion, M., and S. Chen (2017). 'Welfare-Consistent Global Poverty Measures'. World Bank Working Paper 8170. World Bank.

Robeyns, I. (2006). 'The Capability Approach in Practice'. Journal of Political Philosophy, 14(3): 35176.

Rosário, C., I. Tvedten, and M. Paulo (2008). “Mucupuki”. Social Relations of Rural-Urban Poverty in Central Mozambique'. CMI Report 2008:14. Bergen: Chr. Michelsen Institute.

Sainath, P. (1996). Everybody Loves a Good Drought: Stories from India's Poorest Districts. New Delhi: Penguin Books India.

Schaffer, P. (2013). 'Ten Years of "Q-Squared": Implications for Understanding and Explaining Poverty'. World Development, 45: 269-85.

Small, M.L., D.D. Harding, and M. Lamont (2010). 'Reconsidering Culture and Poverty'. Annals of the AAPSS, 629: 6-27.

Starr, M.A. (2014). 'Qualitative and Mixed-Methods Research in Economics: Surprising Growth, Promising Future'. Journal of Economic Surveys, 28(2): 238-64.

Tilly, C. (1998). Durable Inequality. University of California Press.

Tvedten, I. (2011). 'As Long as They Don't Bury Me Here': Social Relations of Poverty in a Namibian Shantytown. Basel: Basel Africa Bibliographies.

Tvedten, I., and S. Candiracci (2018). “Flooding Our Eyes with Rubbish”. Urban Waste Management in Maputo, Mozambique'. Environment and Urbanization (forthcoming).

Tvedten, I., and R. Picardo (2018). “Goats Eat Where They Are Tied Up”. Illicit and Habitual Corruption in Mozambique'. Review of African Political Economy (forthcoming).

Tvedten, I., M. Paulo, and C. Rosário (2006). “'Opitanha”. Social Relations of Rural Poverty in Northern Mozambique’. CMI Report 2006:16. Bergen: Chr. Michelsen Institute.

Tvedten, I., M. Paulo, and C. Rosário (2010). “'Opitanha” Revisited. Assessing the Implications of PARPA II in Rural Northern Mozambique 2006-2009’. Bergen: Chr. Michelsen Institute.

Tvedten, I., M. Tuominnen, and C. Rosário (2016). 'Reality Checks Mozambique. Final Report 2011-2015’. Stockholm: Swedish International Development Cooperation Agency.

UNDP (2017). Human Development Report 2016. Sustainability and Equity. A Better Future for All. New York: United Nations Development Programme. 
Wacquant, L.J.D. (1992). 'Towards a Social Praxeology: The Structure and Logic of Bourdieu's Sociology'. In: P. Bourdieu and L.J.D. Wacquant (eds), An Invitation to Reflexive Sociology. London: Polity Press.

Woolcock, M. (2009). 'Towards an Economic Sociology of Chronic Poverty: Enhancing the Rigour and Relevance of Social Theory'. In: T. Addison, D. Hulme, and R. Kanbur (eds), Poverty Dynamics. Interdisciplinary Perspectives. Oxford: Oxford University Press.

World Bank (2017). World Bank Report 2016. Digital Dividends. Washington, DC: World Bank.

Zhang, Y., X. Zhou, and W. Lei (2017). 'Social Capital and its Contingent Value in Poverty Reduction: Evidence from Western China'. World Development, 93: 350-61. 